Politicization of science: How climate change skeptics use experts and scientific evidence in their online communication

\author{
Hannah Schmid-Petri
}

University of Passau

Dr.-Hans-Kapfinger-Str. 12

94030 Passau, Germany

email: Hannah.Schmid-Petri@uni-passau.de, phone: +49-(0)851-509-3420

\begin{abstract}
:
This study, using the discussion about climate change in the United States as an example, analyzes the research question of how climate change skeptics use experts and scientific evidence in their online communication. Two different strategies are distinguished: legitimation and criticism. The study conducts a quantitative content analysis of online documents to answer the research question. The results show that the deduced strategies are an important part of the communication of climate change skeptics, who more commonly use the criticism strategy than the legitimation strategy. Results are further differentiated for different actor types and various types of experts.
\end{abstract}

Keywords: expert, expert knowledge, online communication, uncertainty, climate change

Acknowledgments:

This publication was created in the context of the Research Unit "Political Communication in the Online World" (1381), subproject 7, which is funded by the DFG, German Research Foundation. The subproject is also funded by the Swiss National Science Foundation (SNF, 100017E-135915). 


\section{Politicization of science: How climate change skeptics use experts and scientific evidence in their online communication}

\section{Introduction}

Political issues and public controversies often refer to scientific knowledge (e.g. about health or environmental protection; Scheufele 2014). In these debates science is often politicized, as actors from both sides strategically use scientific knowledge or intentionally emphasize existing uncertainties to bolster policy goals or avoid certain regulations (Bolsen and Druckman 2015; Pielke 2004; Peters 2008; Zürn, 2014).

One recent example of a politicized scientific issue, especially in the United States, is the discussion of anthropogenic climate change, where a strong skeptical movement is very successful in spreading doubt towards a widely accepted scientific consensus (e.g. Anderegg 2010; Cook et al. 2013), thus avoiding the creation of climate policy regulations (Brulle 2014; Dunlap and McCright 2011; Dunlap et al. 2016; Jacques et al. 2008).

The aim of this study is to gain a more detailed knowledge on the communicative strategies used by climate change skeptics to tackle scientific consensus. Following Sarewitz (2004) who states that those opposing the mainstream view "will either invoke scientific uncertainty or competing scientific results to support their opposition" (Sarewitz 2004, p. 386), two main ways in which experts and scientific evidence can be used in politicized scientific debates are derived: (1) By legitimizing one's own standpoint or convincing the other side or the public of a certain point of view; or (2) by criticizing opponents and discrediting research or scientists who represent the other side (Boswell 2009; Valovirta 2002). Often used by countermovement actors (e.g. climate change skeptics), both strategies oppose the mainstream view, thereby emphasizing conflict and creating an impression of uncertainty and confusion in the public (Corbett and Durfee 2004). This accenting of controversy can be a strategy deliberately used by the countermovement, as binding regulations are seldom realized as long as an issue is discussed and the impression exists that there are still many ambiguities (Freudenburg et al. 2008).

Several studies have been conducted on the journalistic representations of politicized scientific issues (e.g., Boykoff and Boykoff 2004; Friedman et al. 1999; Painter and Ashe, 2012; SchmidPetri et al. 2015), and there is also some research analyzing the content and arguments of the climate change countermovement (e.g., Boussalis and Coan 2016; McCright and Dunlap 2000; Medimorec and Pennycook 2015). These studies have shown that science-related discussions 
POLITICIZATION OF SCIENCE

are a typical element of the countermovement's discourse about climate change (e.g., Bentley et al. 2016; Hoffman, 2011; McCright and Dunlap 2000). However, to date, there has been little evidence of how countermovement actors exactly use experts and scientific evidence for their purposes. The goal of this study is to further existing research and to gain a more detailed knowledge about the concrete communicative strategies that countermovement actors employ to discredit scientific consensus. Thus, the study aims to deepen our knowledge of how exactly skeptical actors discuss scientific aspects of climate change. Furthermore, knowledge of these strategies is relevant for dismantling the concrete construction and representation of talk about uncertainty (Shackley and Wynne 1996, p. 277). Knowing more about the strategies that such actors employ can help us understand the underlying processes, and based on that knowledge, concrete counteractive measures can be designed to mitigate the effects of the arguments (Cook et al. 2017; van der Linden et al. 2017). Additionally, the field of research on the utilization of evaluation in politics focuses on the legitimization function, often termed "symbolic use" (Boswell 2009). The current study widens this perspective by incorporating criticism strategies and, thus, contributes to a theoretical advancement of the use of research in (political) debates.

This study focuses on the online communication of civil-society countermovement actors. Online communication in this regard provides many advantages, for countermovement actors; they are often seen as "weak" actors in public discourse (Kriesi 2004), and compared to the social movement they oppose, are often neglected by traditional media. Thus, they rely strongly on the mobilization of the public for their aims through online communication (Shumate and Lipp 2008). Previous research has shown that the skeptical countermovement is especially active online and that its sites receive many links, thus incorporating a central position in online networks (e.g., Elgesem et al. 2015; Schäfer, 2012; Sharman 2014). As search engines give high ratings to these sites, which are acknowledged by others (e.g., receiving many incoming links), the Internet plays a major role in ensuring the high visibility and accessibility of the countermovement's communication. The relevance of online communication is further bolstered by the fact that the majority of US citizens search for scientific information online $(67 \%$ in 2014, cited by the National Science Board 2016). Moreover, for news about science and technology, more Americans rely on online sources (47\% in 2014, cited by the National Science Board 2016) than on television. Online communication, especially Blogs, forms an integral part of the discussion about climate change; it is a natural part of the media ecology (Klastrup and Pedersen 2006); and it has the potential to influence the agenda of traditional media as well as political processes (Bar-Ilan 2005; Benkler et al. 2017). 
POLITICIZATION OF SCIENCE

Thus, the overall research question of this study is: How do climate change skeptics use experts and scientific evidence in their online communication?

\section{The skeptics' use of expert knowledge}

As previous research has shown, discussions around science-related issues form an integral part of the skeptical discourse about climate change. For example, in their analysis of documents by conservative think tanks, McCright and Dunlap (2000) identify three main counter-claims, one of which deals with science and the evidentiary basis of climate change. This claim centers partly on the emphasis on scientific uncertainty and the accusation that climate research represents junk science (p. 510). Correspondingly, Bentley et al. (2016) find that skeptical statements are factored into five different categories, two of which are science-related and include, inter alia, scientific statements aimed at refuting the occurrence of anthropogenic climate change or arguments attacking mainstream science. In his comparison of convinced vs. denialist frames, Hoffman (2011) shows that skeptics more often use a "diagnostic frame around the issue categories of science and ideology" (p. 29). In their automated content analysis of 16,000 documents stemming from 19 North American think tanks and organizations, Boussalis and Coan (2016) find that science denial is a dominant topic and is gaining momentum relative to discussions on politics/policy topics related to climate change. Furthermore, they show that skeptical actors frequently discuss scientific integrity. To sum up, skeptics discuss scientific issues and the evidentiary basis of climate change and, thus, actively contribute to the politicization of the issue.

"Politicization in general terms means the demand for or the act of transporting an issue into the fields of politics - making previously unpolitical matters political" (Zürn 2014, p. 50) which includes inter alia presenting an issue as open, as a matter of (political) discussion. Following Zürn (2014, p. 51) the agents of politicization can be all individuals or groups who participate in the political process. Thus, in line with this definition the process of politicization also incorporates the communicative tactic to produce doubt regarding a scientific consensus, mainly used by the weaker party in a conflict (Bolsen and Druckman 2015; Ylönen et al. 2017). Based on the work of Sarewitz (2004), this can be implemented by either (1) citing experts or scientific knowledge to legitimate the opposing viewpoint, or (2) by discrediting and criticizing the scientific consensus or its representatives. 
POLITICIZATION OF SCIENCE

The "legitimation strategy" describes the use of experts who share the opinion of the countermovement or scientific studies whose results support the countermovement's claims. This legitimates the countermovement's own standpoints and lends them scientific authority (Boehmer-Christiansen 1995; Boswell 2009; Peters 2008; Weingart 1995). As Peters (2008, p. 141) points out, the authority of a scientific consensus is often so strong "that it usually can be neutralized only by counter-expertise". This means that the countermovement actors must cite their "own" experts and scientific evidence to support their opposing views. Most countermovement actors dispose over a network of experts or institutes that provide them with "critical" or “counter-expertise” (Peters 2008, p. 142; see also Medimorec and Pennycook 2015).

Another way to gain authority in public discourses on scientific issues, and to emphasize controversy regarding a scientific issue, is to criticize the representatives of the scientific consensus, to discredit their scientific credibility or to criticize the studies that are used or their underlying methods or models (Valovirta 2002). This is a very easily applied strategy: criticizing an opponent does not take much effort, nor does it require extensive scientific expertise. The critique can happen either intentionally, or because of a misunderstanding of the experts' positions or of the results of a study (Cook et al. 1980). Nevertheless, this strategy is problematic for the experts themselves because, as scientists, they are dependent on their credibility within the scientific community as well as in public (Nordhagen et al. 2014). In their study, Medimorec and Pennycook (2015) show that the language that skeptics used in the report of the Nongovernmental International Panel on Climate Change (NIPCC) was more certain, less formal, and more emotional than that used in the report of the Intergovernmental Panel on Climate Change (IPCC). They also conclude that skeptics have used the report and the style of the language therein to directly discredit and criticize the IPCC, which gives a first glimpse at the use of the suggested criticism strategies.

Both the legitimation and the criticism strategy contribute to creating an image of uncertainty. First, if the countermovement is successful in persuading a relevant sector of the public with its dissenting views, this accelerates the level of uncertainty about a certain issue as an opposing view arises and gains relevance. Second, the criticism strategy contributes to uncertainty, as it tries to discredit the representatives of scientific consensus or their empirical findings (Leenen and Penders 2016). Smithson (1993, p. 134) mainly identifies interest groups with certain political goals, who "selectively manipulate uncertainty (or ignorance) about scientific matters to their own ends." Following this argument, the present study focuses on civil society countermovement actors. 
POLITICIZATION OF SCIENCE

Previous literature focuses on the legitimating function of research (Amara et al. 2004; Boswell 2009; Peters 2008; Weingart 1995). Until now, studies investigating research utilization have not investigated the criticism strategy. Thus, the first research question is:

RQ1: How frequently do skeptical civil society actors use legitimation and criticism strategies in their online communication?

\section{Online communication: Different types of civil society countermovement actors}

As countermovement actors mostly operate outside the policy process, and have no institutionalized access to political decision making, their most powerful tool is to influence public opinion, and to build public support for their issues (Coombs and Holladay 2012a; Schäfer 2012). Therefore, the Internet holds several advantages: Online, they can easily (and inexpensively) communicate their messages to disparate publics and relevant stakeholders. Furthermore, such communication is direct and controllable, as there are no external gatekeepers like journalists involved (Coombs 2002; Coombs and Holladay 2012b; Taylor et al. 2001). Additionally, online communication facilitates the coordination of actions across national borders (Shumate and Lipp 2008), and it is easy to connect and link to countermovement actors in other countries. Schäfer (2012, p. 530) points out that civil society actors like NGOs "are the champions of online communication." Several studies have shown that actors who belong to minorities or counter-public spheres benefit from the possibilities that the Internet offers (Dahlgren 2005). Thus, it is plausible to assume that an important part of the countermovement actors' communication takes place online, and can be found on their websites.

Civil society actors, especially online, encompass different actor types. There are organizations that act professionally (non-profit organizations, think tanks, or social movements), representing certain groups of civil society, and there are also individual citizens and laypeople in this category (e.g. individual bloggers). To compare likely different strategies within civil society, the two actor types are distinguished in this study, as per their degree of professionalization and organization:

1. Professional organizations: organized actors (e.g., professional non-governmental organizations [NGOs], think tanks, and social movements)

2. Individual citizens/laypeople: non-organized actors (e.g., individual bloggers)

With regards to the legitimation strategy, it is plausible that organizations will normally have a more institutionalized professional background and more financial resources than individual 
POLITICIZATION OF SCIENCE

citizens. Therefore, they may conduct their own studies, from the respective institutes, or pay experts who support their views. Furthermore, because they are more involved in the whole policy process, they normally have easier access to experts than laypeople do. Thus, it is easier for them to legitimate their skeptical viewpoints with corresponding scientific expertise than it is for individual citizens. As such, it is plausible to assume that professional organizations will differ in their communication strategies from individual citizens. As such:

Hypothesis 1a: Professional organizations more often use the legitimation strategy in their communications than individual citizens do.

In contrast, the criticism strategy requires less effort compared to the legitimation strategy. Simply criticizing an actor or a study for its bad scientific quality, methods or models appears easier (and less expensive) than finding an expert who can testify for the favored but contradictory (in terms of scientific consensus) position. Therefore, the hypothesis is:

Hypothesis 1b: Individual citizens more often use the criticism strategy in their communications than professional organizations do.

\section{Who are the experts, and what counts as expert knowledge?}

The complex and dynamic issues of "post-normal" science have led to a situation where no single expert can provide competent advice on all aspects of a scientific issue (Peters 2008). Thus it is necessary to rely on different experts and various perspectives to interpret and evaluate a given scientific problem. From a normative standpoint, as Javeline and Shufeldt write,

... there are no guidelines for whose testimony should best represent the state of science on a given question. Instead, an arbitrary process prevails among both parties of inviting well-connected or well-known scientists from academia, industry think tanks, and non-governmental organizations. (2014, pp. 123-124)

In most cases it is thus difficult to distinguish between expert and non-expert knowledge (Jasanoff 1987), since the number and type of scientists, experts, and the respective institutions that produce research have broadened (Maasen and Weingart 2005). According to Stone (2001), research can be defined as

... a codified, scholarly and professional mode of knowledge production that has its prime institutional loci in universities, policy analysis units of government departments 
POLITICIZATION OF SCIENCE

or international organizations and private research institutes and is produced by academics, think tank experts and (policy) professionals. (Stone 2001, cited in Boswell 2009, p. 4)

Thus two elements define an expert or expert knowledge: 1) The professional mode of production (i.e., following certain rules and procedural requirements), and 2) the institutional setting (see also Boswell 2009). Following this, definitions of four types of experts / producers of expert knowledge are distinguished in this study: 1) Universities / scientific associations; 2) governmental scientific agencies / policy research professionals; 3 ) international organizations (i.e., non-governmental organizations) / think tanks; and 4) private market research institutes.

When looking at different types of civil society and considering hypothesis 1 , we can assume that professional countermovement organizations do not often refer to scientists from universities, as they will most likely represent the scientific consensus. As described above, it is more plausible to assume that these organizations have established their own network of experts who support their opposing views "typically under the auspices of think tanks" (Medimorec and Pennycook, 2015, p. 598). Therefore, hypothesis 2a states:

Hypothesis 2a: Professional organizations more often use experts from international organizations / think tanks to legitimate their position than individual citizens do.

Individual citizens, on the contrary, are more likely to critcize scientific consensus. Because this consensus is mainly represented by universities and governmental scientific agencies, we can assume that their attacks will focus on these institutions or their representatives.

Hypothesis 2b: Individual citizens more often criticize experts from universities or governmental scientific agencies than professional organizations do. 


\section{Methods and measurement}

\subsection{Sampling procedure}

This study uses a technique which takes the hyperlink structure of the web into account, and therefore assures that the whole breadth of the countermovement civil society actors' online communication is considered. First, the eight ${ }^{1}$ most important civil society actors in the field of climate change in the US (four climate advocates and four climate skeptics) were identified. The climate-related pages of these identified actors were then used as source seeds for crawling software (Govcom.org's Issue Crawler) which follows internal and external links using a snowballing technique (for more details see online Appendix A). The result is a network in which the actors with their websites are the "nodes," and the edges are the hyperlinks between them.

However, one peculiarity of online communication is that it crosses national borders, as it is relatively easy for countermovement actors to connect and link to like-minded organizations in other countries. The discussion analyzed here represents the online discussion about climate change induced by countermovement actors based in the US. From there on, it is possible that actors from countries other than the US are included in our sample. But, as mentioned above, this transnationality is an essential characteristic of the online world, and these are the actors who are important and visible in the US-based online discussion of the topic.

To adjust the network so that it only contained pages that dealt with climate change or global warming, indexing software (Visual Web Spider) was used that deleted all pages that did not contain the required keywords ${ }^{2}$. Furthermore, we have excluded social networking services, such as Facebook and Twitter, as they are online platforms rather than actors in the issue. Finally, all pages that were part of the network were saved. The networks were produced monthly from June 2012 to May 2013.

Two trained coders coded the position concerning climate change (advocate or skeptic) for each actor in the network as well as the type of the actor (for more details see online Appendix A; Krippendorff's Alpha $=.78$ ). For this study only skeptical actors belonging to the civil society were included ( $N=108)$ and divided into two groups (as described above): $21 \%$ were civil society organizations (e.g., The Heartland Institute, The Global Warming Policy Foundation, and the International Climate Science Coalition) and 79\% were blogs (e.g., the aforementioned "Watts Up With That?" and Judith Curry's blog). As mentioned above, most of this sample

\footnotetext{
${ }^{1}$ Extensive pre-tests showed that a higher number of "source seeds" (i.e., starting points for the crawler software) resulted in networks that contained a great amount of noise and were too large to be processed further.

2 „climate change“ or „global warming“ or „Klimawandel*“ or ,globale* Erwärmung“, thus resulting in English and German websites.
} 
POLITICIZATION OF SCIENCE

contains websites from actors stemming from the US (58\%), but other, mainly English-speaking countries are also included (UK 17\%, Australia 8\%, Canada 7\%, Germany 4\%, New Zealand 2\%, and Switzerland, Malawi, Mexico, and Norway with one actor each). Eleven out of the 23 organizations correspond with the skeptical organizations identified by Farrell (2016). For a complete list of the 108 included organizations and blogs/non-organized actors, see online Appendix A.

To draw a sample of webpages, to analyze the cited experts and mentioned scientific studies on the webpages of these skeptical actors, a sampling procedure like Kalton's (1990) probability proportional size sampling was used. First, a monthly sample of 35 domains was drawn from each network; the domains were weighted by their "inlinks," so that more prominent ones had a greater chance of being included in the sample. Second, we randomly selected one page for each of the 35 domains, which then became part of a quantitative content analysis coding process (for a more detailed description of the method, see anonymized) to measure the strategies used.

\subsection{Measurement of the strategies used}

Both strategies can be used in terms of experts (actor-oriented strategy) or in terms of scientific evidence (i.e., scientific studies or content-oriented strategy); both are described in more detail below.

Actor-oriented strategy. Actor-oriented strategies are defined as the citation of experts or of scientific institutions/organizations - either to legitimate one's own standpoint or to criticize the scientific consensus. To measure this strategy, the coders had to identify the three most important actors (MIAs) for each webpage who directly or indirectly state a position toward climate change $(N=529)$. For all identified MIAs was then coded to which group the actor belonged. For this study, only the MIAs who were scientists/experts or scientific institutions/organizations were relevant $(N=279)$. According to Stone's definition (2001, cited in Boswell 2009 , p. 4), the following types were distinguished:

- Universities/scientific associations $(n=165)$

- Governmental scientific agencies $(n=92)$

- International organizations / think $(n=22)$

- Private research institutes $(n=0)$ 
POLITICIZATION OF SCIENCE

We coded the MIAs according to whether they stated that climate change occurred or not, and what causes, consequences, or treatment recommendations they mentioned in the document related to climate change. With these variables the actor could be classified as a climate advocate or a climate skeptic (see online Appendix A for more details).

A "legitimation" took place in cases where countermovement civil society actors cited experts or scientific institutions/organizations that supported their views (i.e., a skeptical actor who cited a skeptical expert). A "critique" was defined as the citation of an expert or scientific institution/organization that represented the opposing camp (i.e., a skeptical actor cited an expert who belonged to the climate change advocates). I assumed that in cases where a countermovement actor cited an expert or scientific institution/organization that stood for the scientific consensus, he or she did so in a criticizing manner ${ }^{3}$.

Content-oriented strategy. Content-oriented strategies were defined as those that cited scientific studies or scientific data (e.g., "scientific studies say that ..." or "scientific data proves that ...”). Thus, for each countermovement actor, we coded whether they cited scientific evidence (up to three times). For each study, we also recorded if the study supported or contradicted anthropogenic climate change and if the scientific quality of the study was assessed (good quality; low quality; the research designs/methods/models used are not adequate; etc.). ${ }^{4}$

For content (the cited scientific studies), a "legitimation" was measured in cases where the countermovement actors cited studies that contradicted anthropogenic climate change. A "criticism" strategy was measured when a study in support of anthropogenic climate change was mentioned.

The coding was completed by six trained coders. Reliability scores for all variables were satisfactory (Krippendorff's Alpha = .79; see online Appendix A for detailed reliability scores).

In a final step, the coded pages were aggregated so that the final unit of analysis was countermovement organizations or individual citizens / blogs. ${ }^{5}$ Within this aggregation step, coded strategies were aggregated as well. Thus, for each actor and each strategy, three different utilization types could be distinguished: 1) Civil society actors belonging to the countermovement

\footnotetext{
${ }^{3}$ The criticism of an actor with an opposing view often does not occur as a direct offense or insult but is mentioned more implicitly for example by making an actor appear ridiculous or by using a very ironic language style.

${ }^{4}$ The codebook used is available at url (anonymized)

${ }^{5}$ During the sample period of one year, for one actor (the blog "Watts Up With That?"), several different pages that dealt with climate change were coded. For the analysis, these single pages were aggregated at the actor level.
} 
POLITICIZATION OF SCIENCE

who solely or mostly used one of the strategies; 2) civil society actors belonging to the countermovement who used the criticism and legitimation strategy in a balanced way; and 3) civil society actors belonging to the countermovement who did not use any of the strategies.

\section{Results}

The first research question asks for the frequency of the strategies used by the countermovement civil society actors in their online communication. Of the 108 countermovement actors, $78 \%$ used one or both strategies, while only $22 \%$ did not use any strategy. Thus the strategic use of scientific evidence is an important part of the countermovement civil society actors' online communication.

Overall, the actor-oriented strategy (67\%) is slightly more frequently used than the contentoriented strategy (55\%). Thus, experts (or their institutions) are more often criticized or cited for legitimation than scientific studies are. Comparing the two different strategies (legitimation vs. criticism) reveals that the criticism strategy is more important than the legitimation strategy; members of the countermovement criticize their opponents or scientific findings more often than they use experts or studies to legitimate their standpoint (figure 1and 2). Additionally, the results show country-specific variations regarding the actor-oriented strategies; countermovement actors stemming from the US more frequently use experts to legitimate their views, whereas skeptical actors from other countries more often attack experts representing the scientific consensus.

\section{[figure 1] \& [figure 2]}

Hypotheses $1 \mathrm{a}$ and $1 \mathrm{~b}$ stated that in their communications, professional organizations more often use the legitimation strategy than individual citizens do, and that individual citizens more often use the criticism strategy than professional organizations do. Figure 3 and 4 show that hypothesis 1a is supported by the results: legitimation is more important for civil society organizations than for individual-citizens. This can explained by the fact that organizations are embedded in a professional background, and that they have the resources to pay experts and to order studies that will support their standpoints.

[figure 3] \& [figure 4] 
POLITICIZATION OF SCIENCE

For the criticism strategy (hypothesis 1b), the picture is mixed. In actor-oriented strategies, we see an assumed pattern; in their communications, individual citizens criticize experts who belong to opposing camp more often than organizations do. For the content-oriented strategy, however, the relation changes, as criticizing studies in support of anthropogenic climate change seems to be a technique more often employed by organizations than by individual citizens. Thus, hypothesis $1 \mathrm{~b}$ must be rejected.

As figure 4 shows, content-oriented strategies are generally more important for organizations than for individual citizens. This result can also be explained by the professional background of the organizations; they have the human resources and the necessary knowledge to conduct or order studies that will substantiate their own views and to understand and criticize the opposing camp's studies.

Overall, civil society actors criticized studies that supported the scientific consensus 112 times. Out of these, they criticized the scientific quality (methods and models used, quality of the data, etc.) of $29 \%$ of the studies. For the remaining $71 \%$, there was no quality assessment.

For the type of experts that were cited, hypothesis $2 \mathrm{a}$ assumed that professional organizations more often use experts from international organizations / think tanks to legitimate their position than individual citizens do. Overall, professional organizations cited 25 experts for legitimation. This group included 14 experts from universities (56\%), 5 from (governmental) scientific agencies $(20 \%)$, and 6 from international organizations or think tanks (24\%). In comparison, individual citizens/non-organized actors cited 67 experts to legitimate their standpoints: 38 were from universities (57\%), 24 from governmental scientific agencies (36\%), and 5 from international organizations or think tanks (7\%). Hypothesis $2 \mathrm{a}$ thus is supported by the data that civilsociety organizations cite more experts from international organizations / think tanks than individual citizens do. The results also reveal, however, that scientists and universities are the most important experts for both groups to legitimate their views. This is surprising, particularly because the overwhelming majority of scientists share the scientific consensus that climate change occurs, and that humans have at least some impact on global warming.

The question that arises from these results is which scientists are used for legitimation purposes. In other words, do countermovement actors rely on a small group of scientists and cite the same persons all the time, or are they able to return to a wide range of scientists to legitimate their positions? Taking a closer look at the scientists who were cited for legitimation purposes $(n=$ 52) reveals that civil society actors cited 41 different scientists with various university affiliations; in 11 cases, only unspecified groups of "scientists" or "study authors" were mentioned. 
POLITICIZATION OF SCIENCE

This reveals that countermovement actors seem to be very successful in establishing their own network of scientists within universities.

Hypothesis $2 \mathrm{~b}$ stated that individual citizens more often criticize experts from universities or governmental scientific agencies than professional organizations do. Overall, individual citizens criticized 145 experts (57\% from universities, 37\% from governmental scientific agencies, and $6 \%$ from international organizations / think tanks). Professional organizations criticized 44 experts $(66 \%$ from universities, $27 \%$ from governmental scientific agencies, and $7 \%$ from international organizations / think tanks). The results show that both types of civil society actors mostly criticize experts from universities or governmental scientific agencies. Thus, hypothesis $2 \mathrm{~b}$ must be rejected.

\section{Discussion}

The key research question in this study asked how scientific experts and scientific evidence are used by climate change skeptics in their online communication. Overall, the results show that the criticism strategy is more commonly used than the legitimation strategy and that mostly legitimation as well as criticism are realized through reference to certain scientific actors or experts.

Comparing the different actor types of civil society reveals that the legitimating function of experts and scientific evidence is more important for organizations. Further, organizations criticize scientific studies more often, whereas individual citizens direct their criticism more at the experts themselves. These differences in the communication strategies can be explained by the more institutionalized backgrounds and the larger financial resources that organizations wield, as they can afford to pay their own experts or to conduct their own studies (or to order them). Organizations also have the know-how to understand the scientific background and to criticize individual aspects of studies. For individuals, even if they are influential bloggers, it is easier to criticize a person and to discredit his or her credibility.

Analysis of the type of experts that organizations use for legitimation purposes, shows that countermovement organizations rely on a broad network of scientists. Contrary to the prior assumptions, organizations do not have to depend on think tanks or other organizations that support their views. As Peters (2008) notes, public opinion on scientific consensus can only be disrupted by counter-expertise. From a normative perspective this development is dangerous, 
POLITICIZATION OF SCIENCE

as it can undermine scientific consensus. The citation of scientists working at different universities spreads a solid and credible image, and has the potential to persuade a certain percentage of the public (see also van der Linden et al. 2017).

The communication strategies identified in this study may have different impacts on the public perception of climate change and on the experts themselves. First, they help emphasize uncertainty as they promote controversy. Given its low access barriers, online communication offers many possibilities, particularly for countermovement actors, to campaign for their cause, especially to discredit their opponents. This finding gains relevance as more people search for information online (National Science Board 2016). From a normative standpoint, this visibility online may be problematic since "to the outside world, seeing the debate through the prism of the Internet, it would not be obvious that the mavericks were doing anything out of the ordinary in respect of their science" (Collins 2014, p. 725). Second, the criticism of experts, scientific institutions, or scientific evidence that represent the consensus regarding anthropogenic climate change is highly problematic for the experts themselves, as they bear the risk of losing their credibility within their own community or in the public debate the issue. Additionally, studies have shown that distrust in scientists leads to a rejection of evidence (Cook et al. 2016). As shown in the experiments conducted by Cook et al. (2017) and van der Linden et al. (2017), inoculation could be an effective way of neutralizing the effects of such misleading information about climate change and to "protect" the "positive effect of the consensus message in the presence of counterinformation" (van der Linden et al. 2017, p. 4). Inoculation in this context means, for example, that journalists explain to their readers that there are special techniques and strategies (e.g., the use of fake experts or legitimation and criticism strategies, as defined in this study) aimed at creating uncertainty and doubt in the scientific evidence about climate change.

The frequent use of the criticism strategy shows that the theoretical extension of the symbolic use of research through a criticizing function seems to be a very fruitful approach. The use of experts and expert knowledge as critique should therefore be integrated into a wider theory of the utilization of research / evaluation, and should be considered in further research. Additionally, our results reveal country-specific differences. As there is a powerful countermovement in the US, it seems plausible that countermovement actors would find experts in the US who they can cite to legitimate their viewpoints. Research in the future should consider these contextual factors and the specific structure of the discourse about a certain issue within a country to develop more insights regarding how these aspects may influence the strategic use of scientific 
POLITICIZATION OF SCIENCE

knowledge. This study focuses on the US context. However, research has shown that the online networks of the skeptical countermovement in other countries are strongly influenced by US actors (see, e.g., Häussler et al. 2017). This transnational focus of domestic debates about climate change presents the US with a pioneering role and it seems plausible to assume that the strategies used by the US countermovement may serve as a model for skeptical actors in other countries.

A limitation of the present study is its focus on civil society actors. Although this group is especially relevant, it would also be interesting to examine other more established actor types (e.g., politicians) of the countermovement, including their utilization of experts and expert knowledge to create uncertainty.

Overall, the countermovement's use of the strategies described in this paper show that climate change still is a politicized scientific issue. The skeptics try to convey the impression among the public that there are still conflictual positions within science and as such try to undermine the actually existing scientific consensus. 
POLITICIZATION OF SCIENCE

\section{References}

Amara N, Ouimet M, Landry R (2004) New evidence on instrumental, conceptual and symbolic utilization of university research in government agencies. Science Communication 26:75-106

Anderegg WRL (2010) Moving beyond scientific agreement. Climatic Change 101:331-337

Bar-Ilan J (2005) Information hub blogs. Journal of Information Science 31(4): 297-307.

Benkler Y, Faris R, Roberts H, Zuckerman E (2017). Study: Breitbart-led right-wing media ecosystem altered broader media agenda. Columbia Journalism Review. https://www.cjr.org/analysis/breitbart-media-trump-harvard-study.php Accessed 23 August 2017

Bentley AP, Petcovic HL, Cassidy, DP (2016). Development and validation of the anthropogenic climate change dissenter inventory. Environmental Education Research: 1-16

Boehmer-Christiansen S (1995) Reflections on scientific advice and EC transboundary pollution policy. Science and Public Policy 22(3):195-203

Bolsen T, Druckman JN (2015) Counteracting the politicization of science. Journal of Communication 65:745-769

Boswell C (2009) The political use of expert knowledge: immigration policy and social research. Cambridge University Press, Cambridge

Boussalis C, Coan TG (2016) Text-mining the signals of climate change doubt. Global Environmental Change 36:89-100

Boykoff MT, Boykoff JM (2004) Balance as bias: Global warming and the US prestige press. Global Environmental Change 14(2):125-136

Brulle RJ (2014) Institutionalizing delay: foundation funding and the creation of U.S. climate change counter-movement organizations. Climatic Change 122(4):681-694

Collins H (2014) Rejecting knowledge claims inside and outside science. Social Studies of Science 44(5):722-735

Cook J, Lewandowsky S (2016) Rational irrationality: Modeling climate change belief polarization using Bayesian networks, Topics in Cognitive Science 8(1):160-179 
POLITICIZATION OF SCIENCE

Cook J, Lewandowsky S, Ecker U (2017) Neutralizing misinformation through inoculation: Exposing misleading argumentation techniques reduces their influence. PLOS ONE $12(5)$

Cook J, Nuccitelli D, Green SA, Richardson M, Winkler B, Painting R, Way R, Jacobs P, Skuce A (2013) Quantifying the consensus on anthropogenic global warming in the scientific literature. Environ Res Lett 8:1-7

Corbett JB, Durfee JL (2004) Testing public (un)certainty of science. Media representations of global warming. Science Communication 26(2):129-151

Cook TD, Levinson-Rose J, Pollard WE (1980) The Mis-Utilization of evaluation research: some pitfalls of definition. Knowledge 1:477-498

Coombs WT (2002) Assessing online issue threats: Issue contagions and their effect on issue prioritisation. Journal of Public Affairs 2(4):215-229

Coombs WT, Holladay SJ (2012a) Fringe public relations: How activism moves critical PR toward the mainstream. Public Relations Review 38:880-887

Coombs WT, Holladay SJ (2012b) Privileging an activist vs. a corporate view of public relations history in the U.S. Public Relations Review 38(3):347-353

Dahlgren, P. (2005). The Internet, Public Spheres, and Political Communication: Dispersion and Deliberation. Political Communication, 22(2):147-162.

Dunlap RE, McCright AM (2011) Organized climate change denial. In: Dryzek JS, Norgaard RB, Schlossberg D (eds) The Oxford Handbook of Climate Change and Society. Oxford University Press, Oxford, pp 144-160

Dunlap RE, McCright AM, Yarosh JH (2016) The political divide on climate change: Partisan polarization widens in the U.S. Environment: Science and Policy for Sustainable Development 58(5):4-23

Elgesem D, Steskal L, Diakopolous N (2015) Structure and content of the discourse on climate change in the blogosphere: the big picture. Environmental Communication 9(2):169188.

Farrell J (2016) Corporate funding and ideological polarization about climate change. PNAS 113(1):92-97

Friedman SM, Dunwoody S, Rogers CL (1999) (eds) Communicating uncertainty. Media coverage of new and controversial science. Lawrence Erlbaum, Mahwah, New Jersey 
POLITICIZATION OF SCIENCE

Freudenburg WR, Gramling R, Davidson DJ (2008) Scientific Certainty Argumentation Methods (SCAMs): Science and the Politics of Doubt. Sociological Inquiry 78(1):2-38

Häussler, T, Adam, S, Schmid-Petri, H, Reber, U. (2017). How Political Conflict Shapes Online Spaces: A Comparison of Climate Change Hyperlink Networks in the United States and Germany. International Journal of Communication 11: 3096-3117

Hoffman AJ (2011) Talking past each other? Cultural framing of skeptical and convinced logics in the climate change debate. Organization \& Environment 24(1):3-33

Jaques PJ, Dunlap RE, Freeman M (2008) The organization of denial: Conservative think tanks and environmental skepticism. Environmental Politics 17(3):349-385

Jasanoff S (1987) Contested boundaries in policy-relevant science. Social Studies of Sciences $17: 195-230$

Javeline D, Shufeldt G (2014) Scientific opinion in policymaking: the case of climate change adaption. Policy Sciences 47:121-139

Kalton G (1990) Introduction to Survey Sampling. Sage, London

Klastrup L, Pedersen PS (2006) Blogging for the election: The use and function of blogs as communication tool in a Danish Parliament election campaign. Internet research annual 2005 - Selected papers from the Association of Internet Researchers Conference 2005.

Kriesi H (2004) Strategic political communication: mobilizing public opinion in , audience democracies'. In: Esser F, Pfetsch B (eds) Comparing Political Communication. Theories, cases, and challenges. Cambridge University Press, Cambridge, pp 184-212

Leenen M, Penders B. (2016) Dissident dietary credibility: The power of discontent. Science Communication 38(5):551-573

Maasen S, Weingart P (2005) What's new in scientific advice to politics? In: Maasen S, Weingart P (eds) Democratization of Expertise? Exploring novel forms of scientific advice in political decision-making. Springer, Dordrecht, pp 1-19

McCright AM, Dunlap RE (2000) Challenging global warming as a social problem: An analysis of the conservative movement's counter-claims. Social Problems 47(4):499-522

Medimorec S, Pennycook G (2015) The language of denial: text analysis reveals differences in language use between climate change proponents and skeptics. Climatic Change 133:597-605 
POLITICIZATION OF SCIENCE

National Science Board (2016) Science and Engineering Indicators 2016. National Science Foundation. https://www.nsf.gov/statistics/2016/nsb20161/\#/report/chapter-7/interestinformation-sources-and-involvement Accessed 24 August 2017

Nordhagen S, Calverley D, Foulds C, O’Keefe L, Wang X (2014) Climate change research and credibility: balancing tensions across professional, personal, and public domains. Climatic Change 125:149-162

Painter J, Ashe T (2012) Cross-national comparison of the presence of climate scepticism in the print media in six countries, 2007-10. Environmental Research Letters 7(4):1-8

Peters HP (2008) Scientists as public experts. In: Bucchi M, Trench B (eds) Handbook of Public Communication of Science and Technology. Routledge, London, New York, p 131-146

Pielke RA Jr. (2004). When scientists politicize science: making sense of controversy over The Skeptical Environmentalist. Environmental Science and Policy:405-417

Rahmstorf S (2004) The climate skeptics: In weather catastrophes and climate change: Is there still hope for us? http://www.pik-potsdam.de/ stefan/Publications/ Accessed 3 September 2015

Sarewitz D (2004) How science makes environmental controversies worse. Environmental Science and Policy 7:385-403

Schäfer MS (2012) Online Communication on Climate Change and Climate Politics: A Literature Review. WIREs Clim Change 3:527-543

Sharman A (2014) Mapping the climate sceptical blogosphere. Global Environmental Change 26:159-170.

Scheufele DA (2014) Science communication as political communication. PNAS 111(4):13585-13592

Schmid-Petri H, Adam S, Schmucki I, Häussler T (2015) A changing climate of skepticism? The factors shaping climate change coverage in the US press. Public Understanding of Science. Online first, doi: 10.1177/0963662515612276

Shackley S, Wynne B (1996) Representing uncertainty in global climate change science and policy: Boundary-ordering devices and authority. Science, Technology and Human Values 21:275-302 
POLITICIZATION OF SCIENCE

Shumate M, Lipp J (2008) Connective collective action online: An examination of the hyperlink network structure of an NGO issue network. Journal of Computer-Mediated Communication $14(1): 178-201$

Smithson M (1993) Ignorance and Science: Dilemmas, Perspectives, and Prospects. Science Communication 15:133-156

Stone D (2001) Getting research into policy. Paper presented at the Global Development Network, Conference on 'Blending Local and Global Knowledge', Rio De Janeiro, 10th December 2001.

Taylor M, Kent ML, White WJ (2001) How activist organizations are using the Internet to build relationships. Public Relations Review 27(3):263-284

Valovirta V (2002) Evaluation utilization as argumentation. Evaluation 8:60-80

van der Linden S, Leiserowitz A, Rosenthal S, Maibach E (2017) Inoculating the public against misinformation about climate change. Global Challenges 1(2)

Weingart P (1995) Scientific expertise and political accountability: Paradoxes of science in politics. Science and Public Policy 26:151-161

Ylönen M, Litmanen T, Kojo M, Lindell P (2017) The (de)politicisation of nuclear power: The Finnish discussion after Fukushima. Public Understanding of Science 26(3):260-274

Zürn M (2014) The politicization of world politics and its effects: Eight propositions. European Political Science Review 6(1): 47-71 
POLITICIZATION OF SCIENCE

Figure 1: Use of the actor-oriented strategy by countermovement civil-society actors

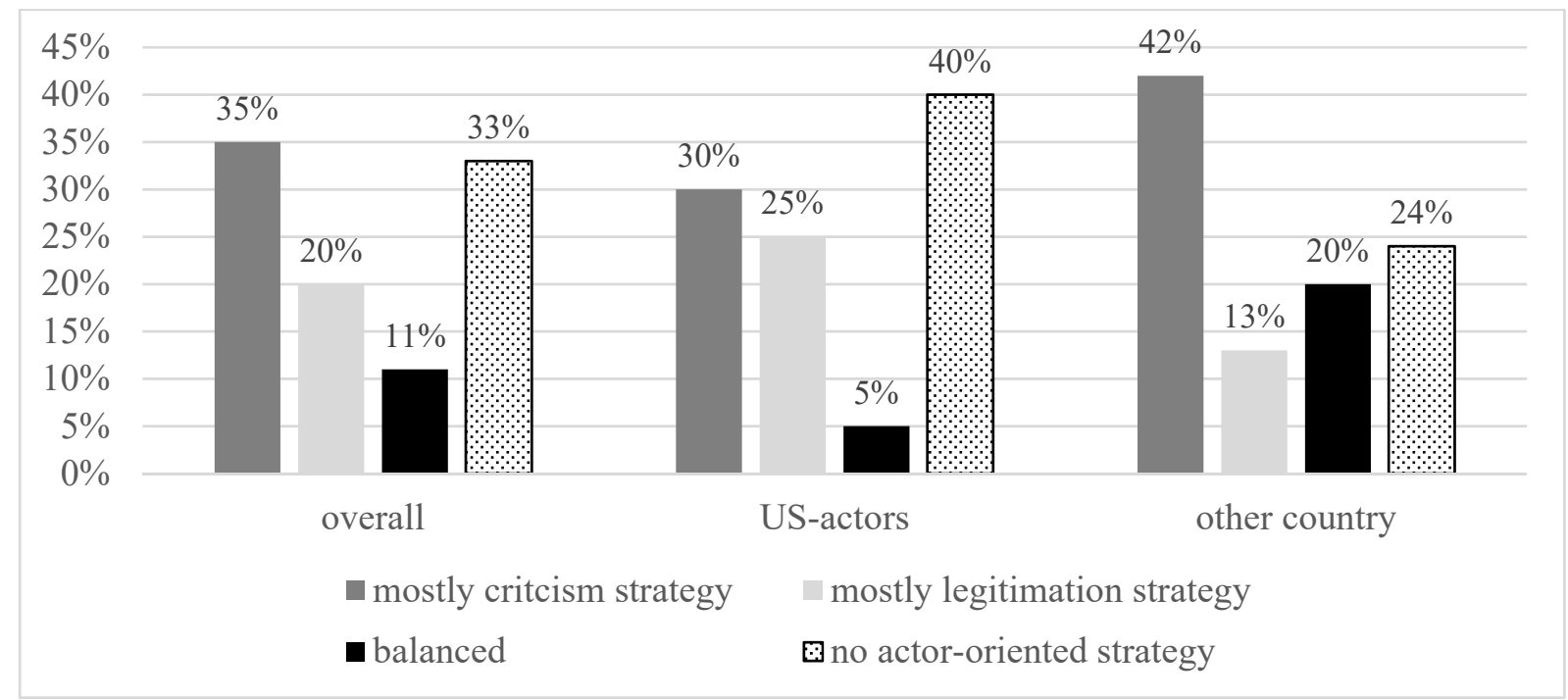

$N=108$ all countermovement civil-society actors

overall: $\chi^{2}=17.32, p<.005 / /$ country-comparison Cramer's $V=0.30, p<0.05$

Figure 2: Use of the content-oriented strategy by countermovement civil-society actors

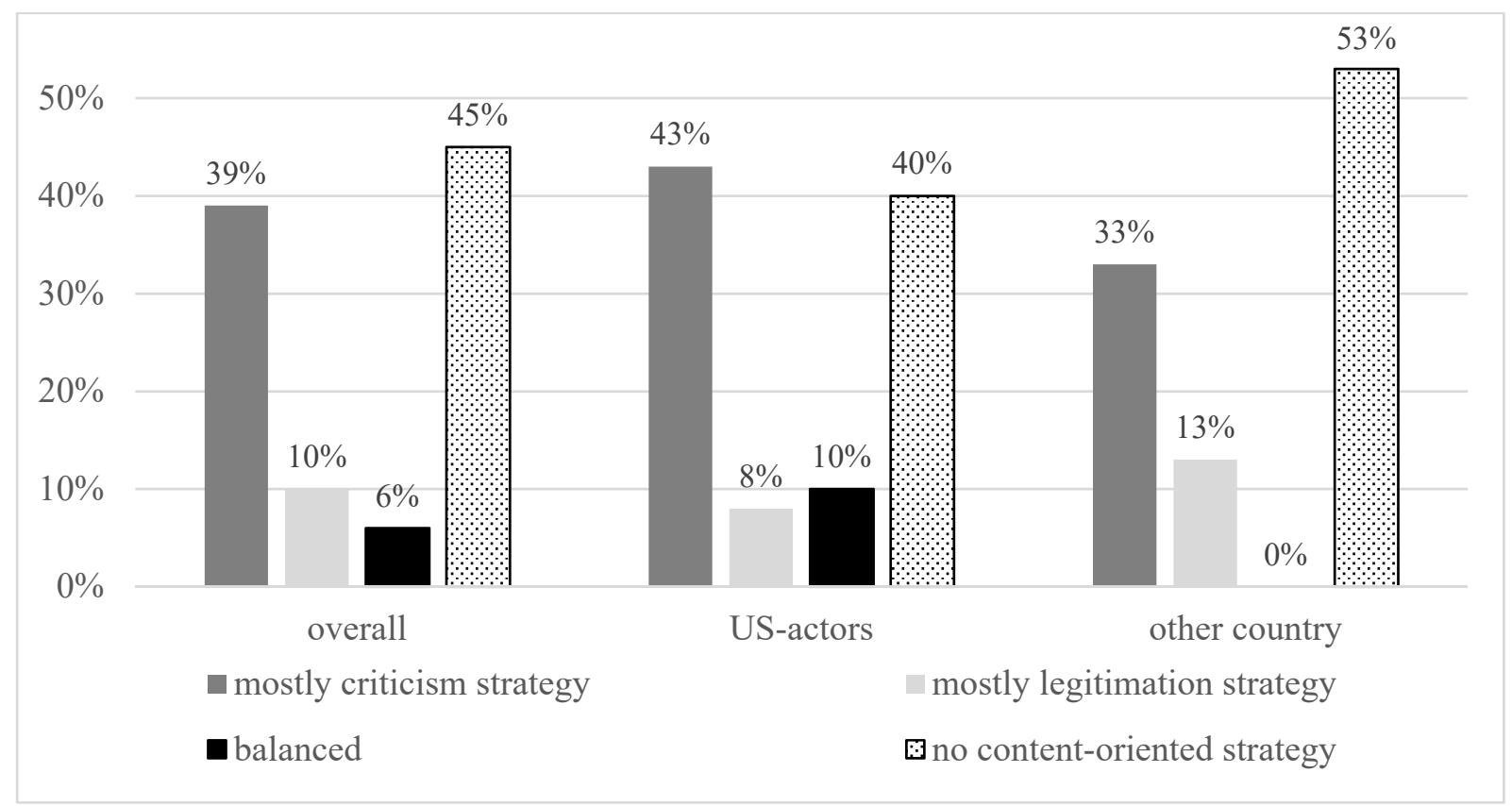

$N=108$ all countermovement civil-society actors

overall: $\chi^{2}=55.02, p<.001 / /$ country-comparison Cramer's $V=0.25$, n.s. 
POLITICIZATION OF SCIENCE

Figure 3: Use of the actor-oriented strategy by different types of civil-society actors

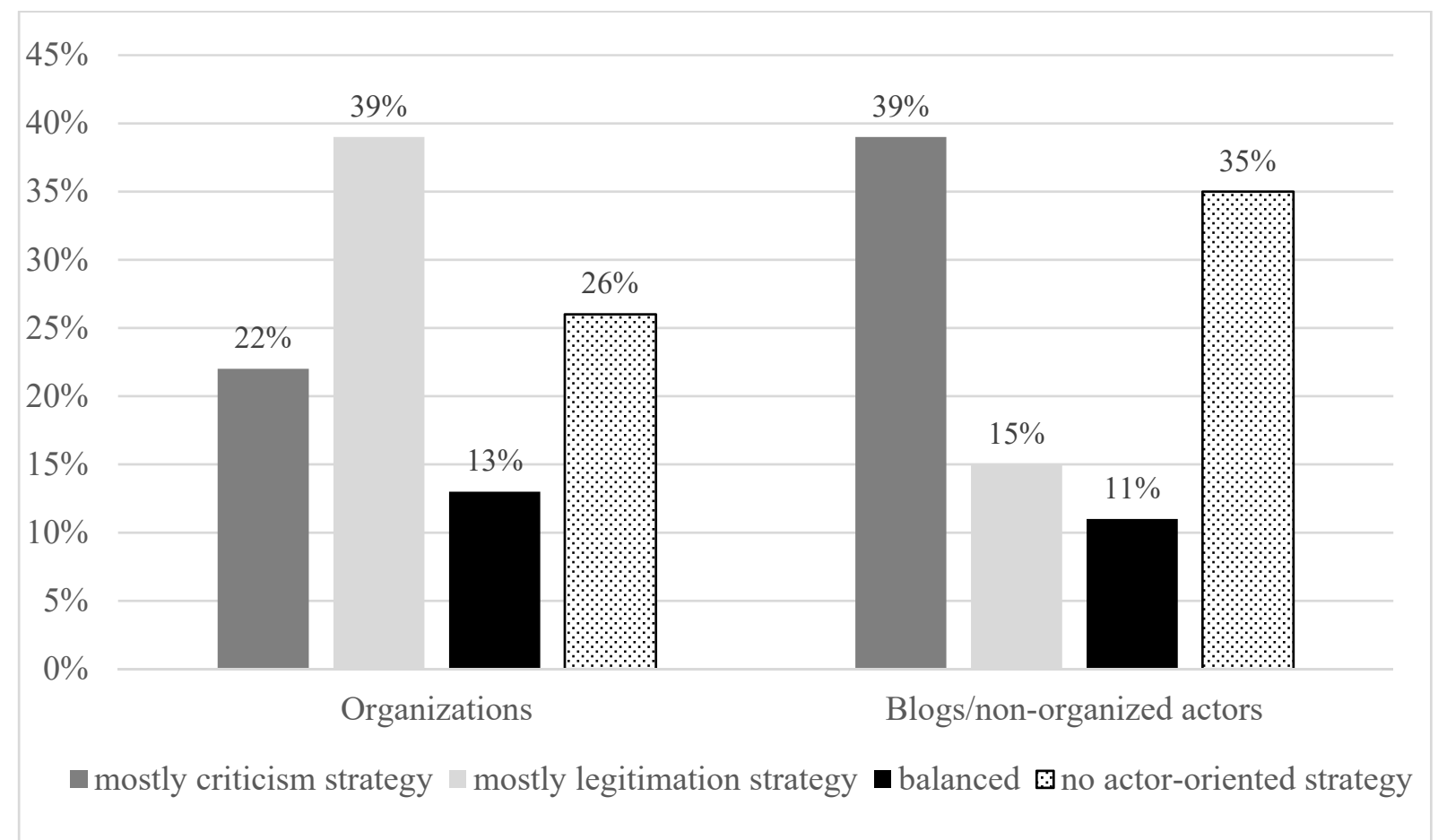

$N=23$ countermovement organizations and 85 countermovement blogs/non-organized actors Cramer's $V=0.26, p=0.06$

Figure 4: Use of the content-oriented strategy by different types of civil-society actors

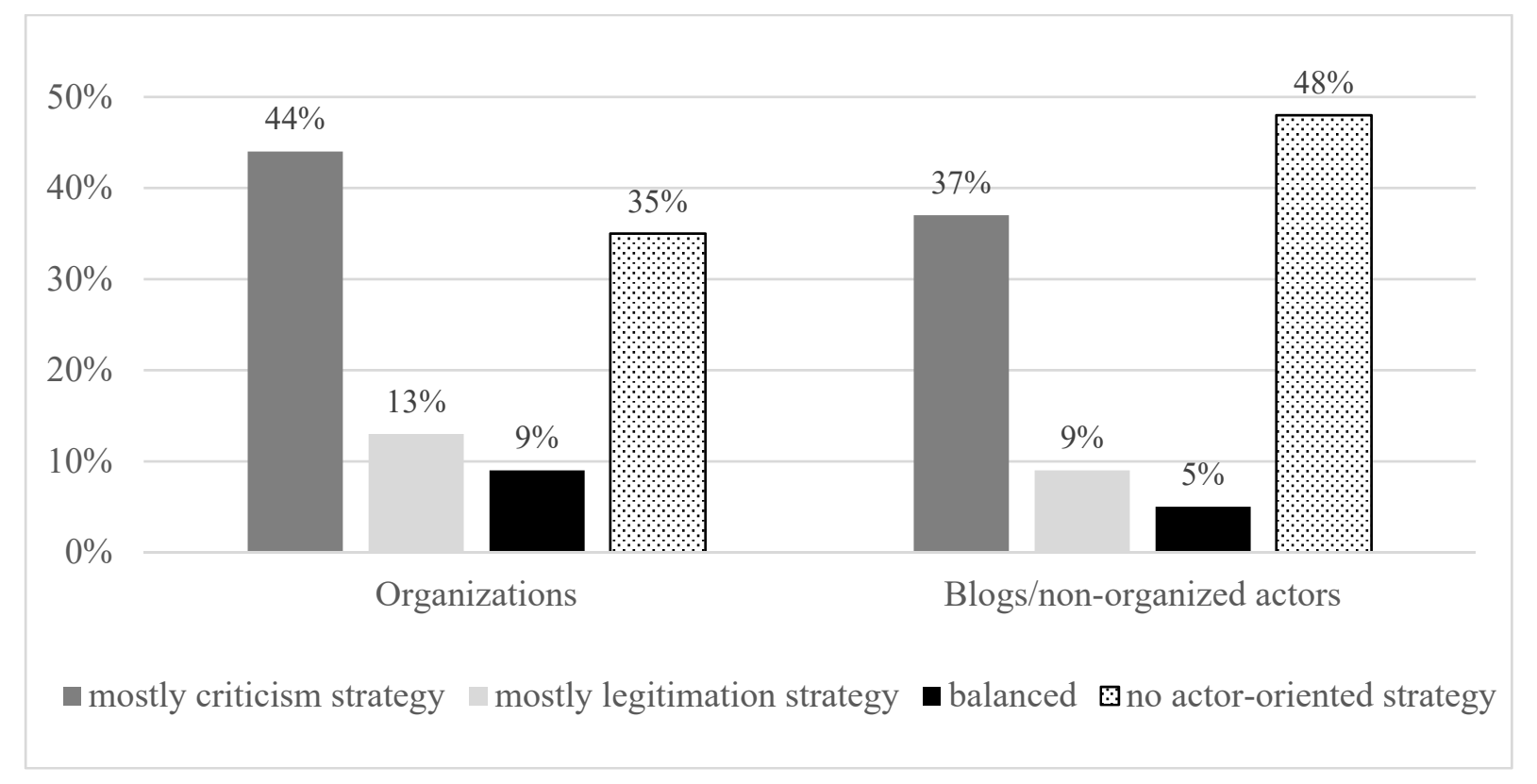

$N=23$ countermovement organizations and 85 countermovement blogs/non-organized actors Cramer's $V=0.12$, n.s. 


\section{Appendix A: Detailed information about methods and measurement}

\section{Sampling Procedure}

First, the eight ${ }^{6}$ most important civil society actors in the field of climate change in the US (four climate advocates and four climate skeptics) were identified through the combination of "clean" Google searches with deleted search histories (keywords: "climate change" and "global warming") to describe the issue field. This search was validated by a review of the literature and expert interviews. These actors include the US affiliation of internationally operating non-governmental organizations on the side of the climate advocates, such as Greenpeace and the World Wildlife Fund, as well as country-specific organizations, such as the Worldwatch Institute. The skeptical perspective is represented by, among others, the Heartland Institute, a conservative think tank, and "Watts Up With That?", one of the most prominent skeptical blogs on the web. The climate-related pages of these identified actors were then used as source seeds for crawling software (Govcom.org's Issue Crawler):

Starting URLs (source seeds) used for the issue crawler:

\section{Climate advocates}

- http://www.climatecentral.org

- http://www.greenpeace.org/usa/en/campaigns/global-warming-and-energy

- http://www.worldwatch.org/climate-energy

- http://www.worldwildlife.org/climate/index.html

\section{Climate skeptics}

- http://heartland.org/issues/environment

- http://wattsupwiththat.com

- http://www.c3headlines.com

- http://www.climatedepot.com

A "snowballing" technique was used, meaning that the crawler first searches two steps deep (collecting all internal pages that are no more than two links away from the source seed), then follows all outgoing links, and finally collects all hyperlinks that run within the pages that are already part of the network. The result is a network in which the actors with their websites are the "nodes," and the edges are the hyperlinks between them.

To adjust the network so that it only contained pages that dealt with climate change or global warming, indexing software (Visual Web Spider) was used that deleted all pages that did not contain the required keywords. Furthermore, we have excluded social networking services, such as Facebook and Twitter, as they are online platforms rather than actors in the issue. Pretests showed that the seeds capture the mainstream of the debate and form an integral part of it. The networks are not fragmented into different clusters, but form an entity in which the seeds are well connected to the other actors through short paths.

To adjust the network so that it only contained pages that dealt with climate change or global warming, indexing software (Visual Web Spider) was used that deleted all pages that did not contain the required keywords. Furthermore, we have excluded social networking services, such as Facebook and Twitter, as they are online platforms rather than actors in the issue. Finally, all pages that were part of the network were saved. The networks were produced monthly from June 2012 to May 2013. Two trained coders coded the position concerning climate change (advocate or skeptic) for each actor in the network as well as the type of the actor. Within this

\footnotetext{
${ }^{6}$ Extensive pre-tests showed that a higher number of "source seeds" (i.e., starting points for the crawler software) resulted in networks that contained a great amount of noise and were too large to be processed further.
} 
study, "belonging to the countermovement" means that the actor was identified as being skeptical $^{7}$ toward anthropogenic climate change. This information was gathered by checking the "About us" or "Our mission" sections of the websites for statements related to anthropogenic climate change (Krippendorff's Alpha $=.78$ ). For this study only skeptical actors belonging to the civil society were included $(N=108)$ and divided into two groups (as described above): $21 \%$ were civil society organizations (e.g., The Heartland Institute, The Global Warming Policy Foundation, and the International Climate Science Coalition) and 79\% were blogs (e.g., the aforementioned "Watts Up With That?" and Judith Curry's blog). As mentioned above, most of this sample contains websites from actors stemming from the US (58\%), but other, mainly English-speaking countries are also included (UK 17\%, Australia 8\%, Canada 7\%, Germany 4\%, New Zealand 2\%, and Switzerland, Malawi, Mexico, and Norway with one actor each). Eleven out of the 23 organizations correspond with the skeptical organizations identified by Farrell (2016). For a complete list of the 108 included organizations and blogs/non-organized actors, see the table below:

\section{All countermovement actors:}

\begin{tabular}{|c|c|c|}
\hline Name & type of actor & url \\
\hline Biology Cabinet Organization & Organisation & biocab.org \\
\hline Cato Institute & Organisation & cato.org \\
\hline $\begin{array}{l}\text { Committee for a Constructive To- } \\
\text { morrow }\end{array}$ & Organisation & climatedepot.com \\
\hline $\begin{array}{l}\text { International Climate Science } \\
\text { Coalition }\end{array}$ & Organisation & climatescienceinternational.org \\
\hline ClimateWiki & Organisation & climatewiki.org \\
\hline $\begin{array}{l}\text { Center for the Study of Carbon Di- } \\
\text { oxide and Global Change }\end{array}$ & Organisation & co2science.org \\
\hline $\begin{array}{l}\text { EIKE - Europäisches Institut für } \\
\text { Klima und Energie }\end{array}$ & Organisation & eike-klima-energie.eu \\
\hline Friends of Science Society & Organisation & friendsofscience.org \\
\hline $\begin{array}{l}\text { Geocraft/Plant fossils of West Vir- } \\
\text { ginia }\end{array}$ & Organisation & geocraft.com \\
\hline Global Warming Hoax & Organisation & globalwarminghoax.com \\
\hline Green World Trust & Organisation & greenworldtrust.org.uk \\
\hline $\begin{array}{l}\text { International Climate and Envi- } \\
\text { ronmental Change Assessment } \\
\text { Project }\end{array}$ & Organisation & icecap.us \\
\hline John Locke Foundation & Organisation & johnlocke.org \\
\hline Ludwig von Mises Institute & Organisation & mises.org \\
\hline The Heartland Institute & Organisation & news.heartland.org \\
\hline $\begin{array}{l}\text { Nongovernmental International } \\
\text { Panel on Climate Change }\end{array}$ & Organisation & nipccreport.org \\
\hline $\begin{array}{l}\text { New Zealand Climate Science Co- } \\
\text { alition }\end{array}$ & Organisation & nzclimatescience.net \\
\hline $\begin{array}{l}\text { Oregon Institute of Science and } \\
\text { Medicine }\end{array}$ & Organisation & oism.org \\
\hline Global Waming Petition Project & Organisation & petitionproject.org \\
\hline $\begin{array}{l}\text { Scottish Climate and Energy Fo- } \\
\text { rum }\end{array}$ & Organisation & scef.org.uk \\
\hline Science and Public Policy Institute & Organisation & scienceandpublicpolicy.org \\
\hline Stop Common Purpose & Organisation & stopcp.com \\
\hline
\end{tabular}

\footnotetext{
7 "Skeptical" in this context was defined as being skeptical about anthropogenic climate change and its negative consequences, or as being against binding regulations. An actor was only identified as being a skeptic when a clear statement concerning human-induced climate change was found on the website.
} 


\begin{tabular}{|c|c|c|}
\hline $\begin{array}{l}\text { Global Warming Policy Founda- } \\
\text { tion }\end{array}$ & Organisation & thegwpf.org \\
\hline Al Gore lied & Blog/non-organized actors & algorelied.com \\
\hline American Elephant & Blog/non-organized actors & americanelephant.wordpress.com \\
\hline Applied Information Systems & Blog/non-organized actors & appinsys.com \\
\hline Australian Climate Madness & Blog/non-organized actors & australianclimatemadness.com \\
\hline Autonomous Mind & Blog/non-organized actors & autonomousmind.wordpress.com \\
\hline Bishop Hill & Blog/non-organized actors & bishop-hill.net \\
\hline $\begin{array}{l}\text { Bob Tisdale - Climate Observati- } \\
\text { ons }\end{array}$ & Blog/non-organized actors & bobtisdale.wordpress.com \\
\hline C3 Headlines & Blog/non-organized actors & c3headlines.com \\
\hline The Carbon Sense Coalition & Blog/non-organized actors & carbon-sense.com \\
\hline Musings from the Chiefio & Blog/non-organized actors & chiefio.wordpress.com \\
\hline Climate Change & Blog/non-organized actors & climatechange1.wordpress.com \\
\hline Climate Conversation Group & Blog/non-organized actors & $\begin{array}{l}\text { climateconversation.words- } \\
\text { hine.co.nz }\end{array}$ \\
\hline Climate Lessons & Blog/non-organized actors & climatelessons.blogspot.com \\
\hline Climate Nonconformist & Blog/non-organized actors & $\begin{array}{l}\text { climatenonconformist.word- } \\
\text { press.com }\end{array}$ \\
\hline Climate Realists & Blog/non-organized actors & climaterealists.com \\
\hline Climate Reflections & Blog/non-organized actors & climatereflections.wordpress.com \\
\hline Climate Resistance & Blog/non-organized actors & climate-resistance.org \\
\hline Climate Sanity & Blog/non-organized actors & climatesanity.wordpress.com \\
\hline Climate Science & Blog/non-organized actors & climatescience.blogspot.com \\
\hline Contrary2belief & Blog/non-organized actors & contrary2belief.wordpress.com \\
\hline The Daily Bayonet & Blog/non-organized actors & dailybayonet.com \\
\hline Digital Diatribes & Blog/non-organized actors & digitaldiatribes.wordpress.com \\
\hline Roy Spencer, Ph. D. & Blog/non-organized actors & drroyspencer.com \\
\hline EcoTretas & Blog/non-organized actors & ecotretas.blogspot.com \\
\hline EUReferendum & Blog/non-organized actors & eureferendum.blogspot.com \\
\hline Warning Signs & Blog/non-organized actors & factsnotfantasy.blogspot.com \\
\hline Flying Forth & Blog/non-organized actors & flypro.blogspot.com \\
\hline Free Republic & Blog/non-organized actors & freerepublic.com \\
\hline Global Warming & Blog/non-organized actors & globalwarming.org \\
\hline Global Warming and the Climate & Blog/non-organized actors & $\begin{array}{l}\text { global-warming-and-the-cli- } \\
\text { mate.com }\end{array}$ \\
\hline Is it getting warmer? & Blog/non-organized actors & globalwarming-factorfiction.com \\
\hline Haunting the library & Blog/non-organized actors & hauntingthelibrary.wordpress.com \\
\hline Heliogenic Climate Change & Blog/non-organized actors & heliogenic.net \\
\hline The View From Here & Blog/non-organized actors & hro001.wordpress.com \\
\hline Project Humanbeingsfirst & Blog/non-organized actors & humanbeingsfirst.org \\
\hline $\begin{array}{l}\text { Conquer Climate Change Perman- } \\
\text { ently }\end{array}$ & Blog/non-organized actors & iccep.blogspot.com \\
\hline I Love CO2 & Blog/non-organized actors & iloveco2.com \\
\hline I love my carbon dioxide & Blog/non-organized actors & ilovemycarbondioxide.com \\
\hline Jennifer Marohasy & Blog/non-organized actors & jennifermarohasy.com \\
\hline Skeptic's Corner & Blog/non-organized actors & jer-skepticscorner.blogspot.com \\
\hline Joanne Nova & Blog/non-organized actors & joannenova.com.au \\
\hline John Daly & Blog/non-organized actors & john-daly.com \\
\hline Johneggert's Blog & Blog/non-organized actors & johneggert.wordpress.com \\
\hline Judith Curry & Blog/non-organized actors & judithcurry.com \\
\hline Junk Science & Blog/non-organized actors & junkscience.com \\
\hline Die Klimazwiebel & Blog/non-organized actors & klimazwiebel.blogspot.com \\
\hline The Website of Mark Buckles & Blog/non-organized actors & markbuckles.com \\
\hline MasterResource & Blog/non-organized actors & masterresource.org \\
\hline Micky's Muses & Blog/non-organized actors & mickysmuses.blogspot.com \\
\hline Middlebury Community Network & Blog/non-organized actors & middlebury.net \\
\hline The Reference Frame & Blog/non-organized actors & motls.blogspot.com \\
\hline Shub Niggurath Climate & Blog/non-organized actors & nigguraths.wordpress.com \\
\hline
\end{tabular}


POLITICIZATION OF SCIENCE

\begin{tabular}{|c|c|c|}
\hline NOconsensus & Blog/non-organized actors & noconsensus.com \\
\hline No Frakking Consensus & Blog/non-organized actors & nofrakkingconsensus.com \\
\hline the Air Vent & Blog/non-organized actors & noconsensus.wordpress.com \\
\hline Not a lot of People Know that & Blog/non-organized actors & $\begin{array}{l}\text { notalotofpeopleknowthat.word- } \\
\text { press.com }\end{array}$ \\
\hline NoTricksZone & Blog/non-organized actors & notrickszone.com \\
\hline Numberwatch & Blog/non-organized actors & numberwatch.co.uk \\
\hline The Copper Dome & Blog/non-organized actors & pamelagorman.blogspot.com \\
\hline False Alarm & Blog/non-organized actors & paulmacrae.com \\
\hline P Gosselin & Blog/non-organized actors & pgosselin.wordpress.com \\
\hline Climate Science: Roger Pielke Sr. & Blog/non-organized actors & pielkeclimatesci.wordpress.com \\
\hline Popular Technology & Blog/non-organized actors & populartechnology.net \\
\hline Power and Control & Blog/non-organized actors & powerandcontrol.blogspot.com \\
\hline Search for notability & Blog/non-organized actors & rdrake98.posterous.com \\
\hline Reboot Congress & Blog/non-organized actors & rebootcongress.blogspot.com \\
\hline The Whiteboard & Blog/non-organized actors & rhinohide.wordpress.com \\
\hline Rocket Scienist's Journal & Blog/non-organized actors & rocketscientistsjournal.com \\
\hline Roger Pielke Jr.'s Blog & Blog/non-organized actors & rogerpielkejr.blogspot.com \\
\hline Rossmckitrick & Blog/non-organized actors & rossmckitrick.com \\
\hline Small Dead Animals & Blog/non-organized actors & smalldeadanimals.com \\
\hline Sonicfrog Dot Net & Blog/non-organized actors & sonicfrog.net \\
\hline Real Science & Blog/non-organized actors & stevengoddard.wordpress.com \\
\hline Tallbloke & Blog/non-organized actors & tallbloke.wordpress.com \\
\hline The Global Warming Challenge & Blog/non-organized actors & theclimatebet.com \\
\hline The Gateway Pundit & Blog/non-organized actors & thegatewaypundit.com \\
\hline Pointman's & Blog/non-organized actors & thepointman.wordpress.com \\
\hline The Weather Eye & Blog/non-organized actors & theweathereye.wordpress.com \\
\hline Tom Nelson & Blog/non-organized actors & tomnelson.blogspot.com \\
\hline Tory Aardvark & Blog/non-organized actors & toryaardvark.com \\
\hline Twawki & Blog/non-organized actors & twawki.com \\
\hline Watts Up with That & Blog/non-organized actors & wattsupwiththat.com \\
\hline WEBCommentary & Blog/non-organized actors & webcommentary.com \\
\hline Wong is Wrong & Blog/non-organized actors & wongiswrong.com \\
\hline World Climate Report & Blog/non-organized actors & worldclimatereport.com \\
\hline Biology Cabinet Organization & Organisation & biocab.org \\
\hline
\end{tabular}

To draw a sample of webpages, to analyze the cited experts and mentioned scientific studies on the webpages of these skeptical actors, a sampling procedure like Kalton's (1990) probability proportional size sampling was used. First, a monthly sample of 35 domains was drawn from each network; the domains were weighted by their "inlinks," so that more prominent ones had a greater chance of being included in the sample. Second, we randomly selected one page for each of the 35 domains, which then became part of a quantitative content analysis coding process (for a more detailed description of the method, see anonymized) to measure the strategies used.

\section{Measurement of the strategies used}

Both strategies can be used in terms of experts (actor-oriented strategy) or in terms of scientific evidence (i.e., scientific studies or content-oriented strategy); both are described in more detail below.

Actor-oriented strategy. Actor-oriented strategies are defined as the citation of experts or of scientific institutions/organizations - either to legitimate one's own standpoint or to criticize the scientific consensus. To measure this strategy, the coders had to identify the three most 
important actors (MIAs) for each webpage who directly or indirectly state a position toward climate change $(N=529)$. Actor importance was defined by the space that was devoted to their statements $(N=529)$. MIAs could be individual speakers as well as collective actors who advance their view of the issue in the document, or use descriptions that point clearly to an individual (e.g., "he", "she") or a group of speakers (e.g., "skeptics argue that"), or an institution. The unit of analysis for the coding was thus this actor sequence in a specific document. For all identified MIAs was then coded to which group the actor belonged. For this study, only the MIAs who were scientists/experts or scientific institutions/organizations were relevant $(N=$ 279). According to Stone's definition (2001, cited in Boswell 2009, p. 4), the following types were distinguished:

- Universities/scientific associations (including individuals working for universities or scientific associations): e.g., National Snow and Ice Data Center, American Physical Society, American Chemical Society, National Academy of Science; $n=165$.

- Governmental scientific agencies (including individuals working for these agencies, e.g., policy research professionals): e.g., National Aeronautics and Space Administration (NASA), National Oceanic and Atmospheric Administration (NOAA), National Climatic Data Center (NCDC), IPCC, United Nations Framework Convention on Climate Change (UNFCCC); $n=92$.

- International organizations / think tanks (including individuals working for international organizations / think tanks): e.g., Thomas Jefferson Institute of Public Policy, The Heartland Institute, John Locke Foundation, Global Warming Policy Foundation, Greenpeace; $n=22$.

- Private research institutes (including individuals working for private research institutes); $n=0$.

We coded the MIAs according to whether they stated that climate change occurred or not, and what causes, consequences, or treatment recommendations they mentioned in the document related to climate change. With these variables, it was possible to measure if an expert or scientific organization/institution stated an opinion, and if the actor could be classified as a climate advocate or a climate skeptic. A skeptic was further defined as either a "trend" skeptic (i.e., denying the trend of global warming), an "attribution" skeptic (i.e., accepting the trend, but denying its anthropogenic impact), or an "impact" skeptic (i.e., one who is against binding regulations or who states that the consequences of climate change would in fact be beneficial) (Rahmstorf 2004; Painter and Ashe 2012).

\section{Overview over the sampling and coding procedure:}

1. Identification of skeptical actors online

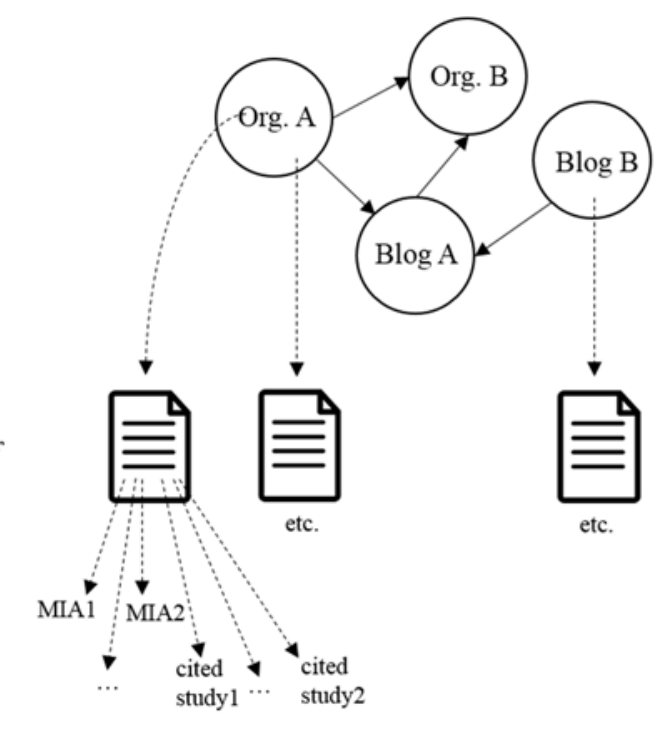


POLITICIZATION OF SCIENCE

\section{Detailed reliability scores for the variables used}

1. Agreement concerning the identification of the three most important actors (MIAs): $77 \%$

2. Variables at the actor-argument level:

\begin{tabular}{ll}
\hline Group the actor belongs to & .82 \\
\hline Occurrence of climate change & .69 \\
\hline Causes of climate change & .75 \\
\hline Consequences of climate change & .76 \\
\hline Treatments & .76 \\
\hline $\begin{array}{l}\text { Type of study (supporting anthropogenic climate change } \\
\text { yes/no/not identifiable) }\end{array}$ & .79 \\
\hline Quality assessment study & .98
\end{tabular}

Basis: N=30 commonly identified MIAs; each coder was compared separately to a master coding 